\title{
Response of traditional upland rice varieties to inoculation with selected diazotrophic bacteria isolated from rice cropped at the Northeast region of Brazil
}

\author{
Antonio Edilson da Silva Araújo ${ }^{\mathrm{a}}$, Vera Lúcia Divan Baldani ${ }^{\mathrm{d}}$, Péricles de Souza Galisa ${ }^{\mathrm{b}, 1}$, \\ José Almeida Pereira ${ }^{c}$, José Ivo Baldani ${ }^{\mathrm{d}, *}$ \\ a Universidade Federal de Roraima, Centro de Ciências Agrárias/EAgro, Campus Murupu, BR 174, Km 35, CEP 69.300-000 Boa Vista-RR, Brazil \\ b UFRRJ/Embrapa Agrobiologia, BR 465, Km 7, CEP 23890-000 Seropédica, RJ, Brazil

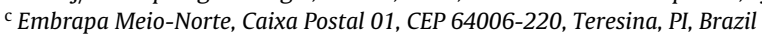 \\ d Embrapa Agrobiologia, BR 465, Km 7, CEP 23890-000 Seropédica, RJ, Brazil
}

\section{A R T I C L E I N F O}

\section{Article history:}

Received 15 February 2012

Received in revised form 11 October 2012

Accepted 15 October 2012

\section{Keywords:}

Nitrogen fixation

Oryza sativa

Plant growth promoting bacteria

Biofertilizer

Burkholderia vietnamiensis

\begin{abstract}
A B S T R A C T
The largest numbers of the Brazilian traditional upland rice varieties are found in the Maranhão state, Northeast region of Brazil. However, no information is available on the diazotrophic bacterial population associated as well as the plant growth promoting potential when these traditional genotypes are inoculated with native strains. Here, we evaluated the response of ten traditional rice varieties to inoculation with ten diazotrophic strains, previously isolated from rice soil of this region and screened for their ability to produce indole-3-acetic acid (IAA) in vitro. The procedure for selection of the best diazotrophic strain/rice variety interaction involved three steps: gnotobiotic conditions, soil pot and field experiments. The gnotobiotic experiment showed that the Azospirillum amazonense strain AR3122 increased the biomass of the traditional varieties Cana Roxa and Cana Forte ( 28 and 48\%, respectively) while this effect was less evident for the other combination of strains/rice varieties. The soil pot experiment showed that the combination of Burkholderia vietnamiensis strain AR 1122 and traditional variety Arroz 70 was superior to the other strains/varieties and the treatment fertilized with $100 \mathrm{~kg} \mathrm{Nha}^{-1}$. The best performance of the Burkholderia vietnamiensis strain AR1122/variety Arroz 70 was confirmed in the field experiment. There was an increase of up 10 and $29 \%$ in the grain yield in comparison to both the $\mathrm{N}$ fertilization and Herbaspirillum seropedicae ZAE 94 strain treatments, respectively. In contrast, the response of the commercial variety Bonança to inoculation with strain AR1122 was much lower, suggesting that a biofertilizer inoculation program for traditional rice varieties should consider the genetic interaction between strain and rice variety. The diazotrophic B. vietmaniensis strain AR1122 was a good biofertilizer candidate for inoculation of traditional rice varieties and therefore should be used for further studies to confirm the strain-genotype effect envisaging a sustainable rice crop system mainly in the Northeast region of Brazil.
\end{abstract}

(c) 2012 Elsevier B.V. All rights reserved.

\section{Introduction}

Rice (Oryza sativa L.) is an excellent source of carbohydrates and proteins and has been considered by FAO a strategic crop for food security of the world population due to its ample adaptation to climates and soils (FAO, 2006). It is well known the need for increasing global rice production to attend the food demand mainly of highly populated countries like China and India. It has been estimated that the global rice production must reach the equivalent to 430 Million tons by the year 2030 (Timmer et al., 2010) and about 455 million of tons by the year 2050 (Mohanty et al., 2010). It is also

\footnotetext{
* Corresponding author. Tel.: +55 213441 1555; fax: +55 2126821230 .

E-mail address: ibaldani@cnpab.embrapa.br (J.I. Baldani).

1 Deceased.
}

expected an increase in the amount of chemical fertilizers to be applied (Gregory et al., 2010); including nitrogen (N) that is the most limiting nutrient for the rice crop (Ladha and Reddy, 2003). The literature has shown that only one- third of the applied $\mathrm{N}$ is utilized by rice plants while the other one-third remains in the soil at the crop harvest and the rest is lost as gas to the atmosphere, mostly through ammonia volatilization (Buresh et al., 2008). Thus, it becomes important to find alternatives to reduce the use of $\mathrm{N}$ fertilizers applied to rice crop without decreasing the productivity and causing risks of environmental pollution.

The association of nitrogen-fixing bacteria or diazotrophs with rice varieties is one alternative that has been strategically thought to replace part of the $\mathrm{N}$ fertilizer required by the plant and in addition, indirectly helping the plant to assess other nutrients added or naturally present in the soil. Many rhizospheric and endophytic diazotrophic species, including Azospirillum brasilense, 
Table 1

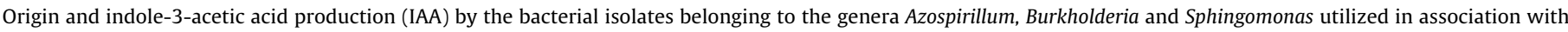
traditional rice cultivar from Maranhão $(\mathrm{Ma})$ state to select strains with potential biofertilizer use.

\begin{tabular}{|c|c|c|c|c|}
\hline Strain identification & Bacterial Species & Locality of soil sampled & $\begin{array}{l}\text { Part of the } \\
\text { plant }^{\mathrm{a}}\end{array}$ & $\begin{array}{l}\text { IAA production } \\
\left(\left(\mathrm{M} \mathrm{mL}^{-1}\right)\right.\end{array}$ \\
\hline AR3122 & Azospirillum amazonense & Arari, Ma & $\mathrm{RD}$ & 186 \\
\hline VR218 & Azospirillum amazonense & Vitória do Mearim, Ma & $\mathrm{RD}$ & 303 \\
\hline VF2213 & Azospirillum amazonense & Vitória do Mearim, Ma & PA & 164 \\
\hline AR2112 & Sphingomonas sp. & Arari, Ma & $\mathrm{RD}$ & 219 \\
\hline BF1358 & Burkholderia vietnamiensis & Bacabal, Ma & PA & 75 \\
\hline AR1135 & Burkholderia sp. & Arari, Ma & $\mathrm{RL}$ & 36 \\
\hline BR2113 & Burkholderia vietnamiensis & Bacabal, Ma & $\mathrm{RD}$ & 16 \\
\hline AR1124 & Burkholderia vietnamiensis & Arari, Ma & $\mathrm{RD}$ & 52 \\
\hline VR2117 & Burkholderia vietnamiensis & Vitória do Mearim, Ma & RL & 32 \\
\hline AR1122 & Burkholderia vietnamiensis & Arari, Ma & $\mathrm{RL}$ & 62 \\
\hline ZAE94-reference biofertilizer strain & Herbaspirillum seropedicae & Seropédica, RJ & $\mathrm{RD}$ & 88 \\
\hline
\end{tabular}

$\mathrm{RL}$ - washed roots; RD - disinfested roots; PA - aerial part.

Azospirillum amazonense, Herbaspirillum seropedicae, Burkholderia tropica, Burkholderia vietnamiensis and Sphigomonas sp., have been found colonizing in high numbers many rice varieties growing in tropical regions (Baldani and Baldani, 2005). It has been demonstrated that certain rice varieties respond positively to inoculation when selected diazotrophic strains from these species were used as biofertilizer (Tran Van et al., 2000; Govindarajan et al., 2008; Rodrigues et al., 2008; Ferreira et al., 2010). In addition, ${ }^{15} \mathrm{~N}$ analysis of inoculated rice varieties indicated that part of the $\mathrm{N}$ accumulated in plant tissues and grains is derived from the biological nitrogen fixation (BNF) process (Baldani et al., 2000; Boddey et al., 1995; Malarvizhi and Ladha, 1999). The literature has also shown that in addition to BNF, some of these inoculated diazotrophic bacteria may also enhance the plant nutrition by using other mechanisms such as production of phytohormones (Peng et al., 2002), siderophore production (Govindarajan et al., 2008) and solubilization of P and Zn (Saravanan et al., 2008). Therefore, selection of efficient strains to enhance yield productivity of rice should consider the characteristics above as well as its ability to establish in the roots and compete with the native microbial community.

The plant genotype, besides environmental factors, is a very important agronomical aspect that should be considered during selection of diazotrophic strains since it may act as selective filter for the rhizospheric and endophytic bacteria that associate with the plants. Recent study carried out with 10 rice cultivars strongly suggested that plant genotype determined the composition of the different bacterial communities across cultivars (Hardoim et al., 2011). The authors observed that traditional and modern rice cultivars are constituted by different bacterial association and suggested that part of this effect may due to the plant breeding strategies for higher-yield crops. In fact, previous studies have already shown that traditional rice varieties harbor bacterial populations different from those found in modern varieties (Engelhard et al., 2000; Knauth et al., 2005). In addition, few reports have also demonstrated the crucial role played by genotypes in the population of diazotrophic endophytic bacteria colonizing rice plant tissues (Elbeltagy et al., 2001; Baldani et al., 2000; Sasaki et al., 2010).

In the Maranhão state, northeast region of Brazil, the largest numbers of traditional Brazilian upland varieties of rice are found (Fonseca et al., 1982). These genotypes are less dependent on $\mathrm{N}$ fertilizer and are more adapted to the region since no or low $\mathrm{N}$ fertilizer level has been applied along the years due to the traditional practice implemented by local farmers (Ferraz Junior et al., 1997). Therefore, these traditional varieties may have acted as a "selective filter" on the diazotrophic bacterial population associated so that only more efficient genotype/bacteria interactions could have been established along the years. So far, no study was carried out on the diazotrophic bacterial population associated with these traditional rice varieties.
The objective of this study was to evaluate the response of traditional rice varieties, grown in a rice crop region of Maranhão state, to inoculation with native diazotrophic bacteria isolated from soil of the same region envisaging the selection of strains with higher growth promoting potential than strain $H$. seropedicae ZAE94, commonly used as biofertilizer in commercial rice varieties cultivated in Brazil.

\section{Materials and methods}

\subsection{Strain isolation and physiological and molecular characterization}

The strains were isolated from different plant tissues (roots, culms and leaves) of the traditional rice varieties Zebu Branco and Manteiga grown in soil collected from three traditional rice crop regions (Arari, Bacabal and Vitória do Mearim) of Maranhão state, Northeast of Brazil. These two and the other traditional rice varieties have been cultivated for many years by the local farmers that traditionally apply very low amount of fertilizers including N. A collection of 228 isolates were obtained from these rice varieties and evaluated for their ability to reduce acetylene in semi-solid media (NFb, JNFb, JMV and LGI) and production of IAA. Ten (10) diazotrophic isolates (checked by acetylene reduction activity) were selected based on their high, medium and low abilities to produce IAA (Table 1). These isolates were further identified based on the almost complete (approximately $1400 \mathrm{bp}$ ) $16 \mathrm{~S}$ rRNA sequences according to the protocol described by Videira et al. (2009) and taxonomically clustered in the genera Azospirillum, Sphingomonas and Burkholderia (Table 1). The strain H. seropedicae ZAE94 was used as a reference biofertilizer inoculant considering its positive effect on commercial rice varieties (Baldani et al., 2000; Guimarães et al., 2003).

\subsection{Gnotobiotic experiment}

The experiment was carried in a complete randomized design with a factorial $11 \times 12$ (11 genotypes and 12 inoculation treatments) and four replicates. Ten strains were used: six (06) of the genus Burkholderia (VR2117, AR1122, AR1124, BR2113, AR1135 and BF1358), three (03) of $A$. amazonense (VR218, VF2213 and AR3122) and one (01) Sphingomonas sp (AR2112). The strain ZAE 94 was used as positive inoculant control while autoclaved cells were applied in the absolute control. Ten traditional varieties of rice developed and cultivated for many decades in a rice crop region of Maranhão state were tested: five (05) with high $(>8 \%)$ crude protein content (Zebu Branco, Arroz 70, Cana Roxa, Bacabinha and Braquiaria) and five (05) with medium/low (6-8\%) crude protein content (Cana forte, Come Cru, Pingo D‘água, Lajeado Liso and 
Bacaba Comprido), according to the criteria established by Araújo et al. (2003). In addition, the commercial variety IR42 (7.82\% crude protein) was used as positive control based on its performance during the selection of strains to inoculate rice (Guimarães et al., 2003).

The assay was carried out in $120 \mathrm{~mL}$ tubes containing $60 \mathrm{~mL}$ Hoagland solution without $\mathrm{N}$ and $6 \mathrm{~g}$ agar $\mathrm{L}^{-1}$ (Baldani et al., 2000). The inoculation was done before the agar solidification (approximately $40-45^{\circ} \mathrm{C}$ ) with $1 \mathrm{~mL}$ culture of each strain, grown in Dygs medium for $16 \mathrm{~h}$ and the Optical Density $(620 \mathrm{~nm})$ adjusted to one (equivalent to $10^{9}$ cells $\mathrm{mL}^{-1}$ ). Before planting, the seeds were disinfested (Baldani et al., 2000) and pre-germinated in agar plates (1\%). Only seedlings free of contaminants were transferred to tubes that were maintained in growth chamber at $25^{\circ} \mathrm{C}$ for 30 days. Then the plants were removed from the agar medium washed and dried with towel paper to remove water excess before determining the dry matter $\left(65^{\circ} \mathrm{C}\right.$ for $72 \mathrm{~h})$.

\subsection{Pot experiment}

The experiment was maintained outside the greenhouse in a randomized block design with a factorial $6 \times 9$ ( 6 genotypes and 9 inoculation treatments) with four replicates. Rice plants were planted in pots containing $4 \mathrm{~kg}$ of a sieved air-dried Planossolo type soil (series Ecologia) showing the following chemical properties: $\mathrm{pH} / \mathrm{H}_{2} \mathrm{O}-5.8 ; \mathrm{Al}-0.1 \mathrm{cmolc} \mathrm{dm}^{-3} ; \mathrm{Ca}+\mathrm{Mg}-0.7 \mathrm{mg} \mathrm{dm}^{-3}$; $\mathrm{Ca}-0.5 \mathrm{mg} \mathrm{dm}^{-3} ; \mathrm{Mg}-0.2 \mathrm{mg} \mathrm{dm}^{-3} ; \mathrm{P}-17.3 \mathrm{mg} \mathrm{dm}^{-3} ; \mathrm{K}-$ $45.6 \mathrm{mg} \mathrm{dm}^{-3}$. A fertilization equivalent to $52.4 \mathrm{~kg} \mathrm{ha}^{-1} \mathrm{P}$ (single superphosphate) and $60 \mathrm{~kg} \mathrm{ha}^{-1}$ micronutrients FTE BR-12 (Fritted Trace Elements) was carried out one week before planting. Four rice varieties selected from the gnotobiotic experiment were used: two from the high (Arroz 70, Braquiaria) and two from the low protein content group (Cana forte, Come Cru). In addition, the modern rice variety Bonança, commonly recommended for cultivation in the Maranhão state, and the commercial variety IR42 were used. The strains were selected from the gnotobiotic experiment based on the higher (AR3122, AR2112, VR218) and lower (AR1122, AR1124, BR2113, BF1358) contribution to the dry weight accumulated in the plants. The strain ZAE 94 was used as reference biofertilizer inoculant control. The $\mathrm{N}$ treatment received the equivalent to $100 \mathrm{~kg} \mathrm{ha}^{-1} \mathrm{~N}$ as ammonium nitrate.

The seeds were inoculated with strains in the proportion of $10 \mathrm{~g}$ of peat $\left(10^{8}\right.$ cells/g peat) $\mathrm{kg}^{-1}$ seed as it has been recommended by Ferreira et al. (2010). The Gum Arabic (10\%) was applied to the seeds before the inoculation with the peat containing bacteria. These inoculated seeds were left to dry in the shade before planting. Eight seeds were planted per pot but only three homogenous seedlings were left after emergence.

The inoculated treatments and control received the equivalent of 20 and $30 \mathrm{~kg} \mathrm{ha}^{-1}$ of $\mathrm{NH}_{4} \mathrm{NO}_{3}$ and $\mathrm{K}_{2} \mathrm{SO}_{4}$, respectively, with the $\mathrm{N}$ applied half dose at 25 days (tillering) and half dose at 50 days after emergence. The $\mathrm{N}$ treatment $\left(100 \mathrm{~kg} \mathrm{ha}^{-1}\right)$ was applied in three split doses: $20 \mathrm{~kg} \mathrm{ha}^{-1}$ at 25 days and two of $40 \mathrm{~kg} \mathrm{ha}^{-1}$ at 50 and 75 days after emergence, respectively. The soil moisture in the pots was maintained at the field capacity. The varieties were harvested according to their physiological grain maturation and the following parameters were evaluated: grain yield (13\% moisture), weight of 1000 grains and crude protein content of grain. The $\mathrm{N}$ content of grains was analyzed according to Tedesco et al. (1995). The $\%$ crude protein of grain was calculated based on the $\mathrm{N}$ content multiplied by the factor 5.95 . This factor is based on the content of $\mathrm{N}(16.8 \%)$ of the glutelin, the principal protein of rice (Juliano, 1985).

\subsection{Field experiment}

The experiment was installed in the Field Experimental Station at Embrapa Meio Norte, Piauí State $\left(5^{\circ} 05^{\prime} \mathrm{S}\right.$ and $\left.42^{\circ} 49^{\prime} \mathrm{W}\right)$, in a randomized block design, disposed in a factorial $3 \times 6$ (three rice varieties and six inoculation treatments) with 4 replicates. The soil analysis showed the following chemical properties: $\mathrm{pH} / \mathrm{H}_{2} \mathrm{O}-6.1$; $\mathrm{Al}-0.1 \mathrm{cmolc} \mathrm{dm}^{-3} ; \mathrm{Ca}+\mathrm{Mg}-7.4 \mathrm{mg} \mathrm{dm}^{-3} ; \mathrm{Ca}-5.9 \mathrm{mg} \mathrm{dm}^{-3} ; \mathrm{Mg}$ $-1.5 \mathrm{mg} \mathrm{dm}^{-3} ; \mathrm{P}-7.8 \mathrm{mg} \mathrm{dm}^{-3} ; \mathrm{K}-310 \mathrm{mg} \mathrm{dm}^{-3}$. The fertilization was based on soil analysis and that recommended for the crop: $52.4 \mathrm{~kg} \mathrm{ha}^{-1} \mathrm{P}$ (single superphosphate) and $50 \mathrm{~kg} \mathrm{ha}^{-1} \mathrm{~K}$ (potassium chloride) applied at the planting time. The traditional variety Arroz 70 , selected from the pot experiment, as well as the modern variety Bonança was used in combination with four diazotrophic strains (AR1122, AR2112, AR3122 and BR2113) also selected from the pot experiment based on the inoculation effect on these varieties. In addition, it was used the reference biofertilizer strain ZAE 94 and the treatment fertilized with $100 \mathrm{~kg} \mathrm{ha}^{-1} \mathrm{~N}$. A dose of $20 \mathrm{~kg} \mathrm{ha}^{-1} \mathrm{~N}$ (Urea) was applied 20 days after emergence in all treatments while the $\mathrm{N}$ treatment $\left(100 \mathrm{~kg} \mathrm{ha}^{-1}\right)$ was applied in two split doses: first (40 kg) applied 20 days and second $(60 \mathrm{~kg}) 50$ days after emergence, respectively. The soil moisture was maintained at the field capacity with water irrigation. The seeds were inoculated in a similar way to the pot experiment and 100 seeds were planted per linear meter. Each plot (three $\mathrm{m}^{2}$ ) contained five lines of two $\mathrm{m}$ length with $30 \mathrm{~cm}$ distance between rows and the three central lines, discarding $0.5 \mathrm{~m}$ each side, were considered as the harvesting area. The grain yield was determined based on one $\mathrm{m}^{2}$ of each plot and the results expressed in $\mathrm{Mg} \mathrm{ha}^{-1}$ (corrected to $13 \%$ moisture). In addition, it was analyzed the weight of 1000 seeds and crude protein content of the grains.

Data were analyzed by analysis of variance and the treatment means were compared relative to controls (uninoculated and strain ZAE 94) following the least significant difference (LSD) test. Unless indicated otherwise, differences were only considered when significant at $P<0.05$.

\section{Results}

Biomass increments of 48, 28 and $21 \%$ were observed for the traditional varieties Cana Forte, Cana Roxa and commercial variety IR42, respectively grown in the gnotobiotic conditions and inoculated with the A. amazonense strain AR3122 as compared to the absolute control (Table 2). This effect was much more pronounced when this strain (AR3122) or the strains AR2112 and VR218 were compared with the reference biofertilizer strain ZAE94. In contrast, inoculation of $B$. vietnamiensis strain AR1122 affected negatively the biomass accumulation and significantly differed from the other strains. Independent from the inoculated strains, the variety Arroz 70 accumulated significantly higher amount of biomass and it was followed by varieties Come Cru, Bacaba Comprido, Cana Roxa and Braquiaria. In contrast, the varieties Lajeado Liso and Bacabinha accumulated significantly less biomass and differed statistically from the other varieties (Table 2).

Analysis of the experiment carried out in pots, containing unsterilized soil, showed that the response to inoculation with selected strains from the gnotobiotic experiment was dependent on the rice varieties. The traditional varieties Arroz 70 and Cana Forte and the modern variety Bonança responded to inoculation of few selected strains and produced higher grain yield than when inoculated with the reference strain ZAE 94 or fertilized with $100 \mathrm{~kg} \mathrm{~N} \mathrm{ha}^{-1}$ (Table 3). The grain yield of variety Arroz 70 was $42 \%$ and $16 \%$, respectively higher when inoculated with strain AR 1122 compared to strain ZAE 94 or fertilized with N. Increments of 10 to $20 \%$ were also observed for variety Cana Forte inoculated with strain VR 218 and, the modern variety Bonança with strains BR2113 


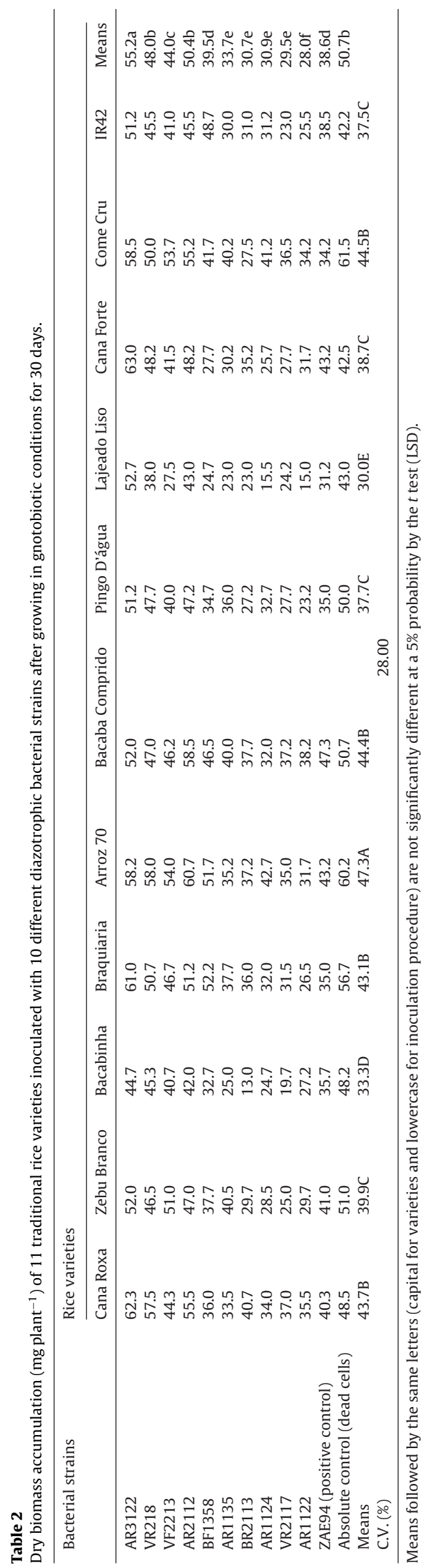

and AR1124 (Table 3). In contrast, a significant reduction of grain yield was observed for the traditional variety Cana Forte and modern variety Bonança inoculated with strain AR2112 and the variety Come Cru inoculated with strain BF1358 when compared with the reference strain ZAE 94. On an average, the commercial variety IR42 produced the highest grain yield as compared to the other traditional rice varieties mainly when fertilized with $100 \mathrm{~kg} \mathrm{~N} \mathrm{ha}^{-1}$ (Table 3).

Analysis of the yield component (1000 grain weight) indicated that the traditional variety Brachiaria accumulated the highest mass weight while it was lower in the commercial variety IR42 and traditional variety Come Cru (Table 4). An interaction between rice genotypes and inoculated strains was observed. The Arroz 70 and IR 42 produced grain with weight significantly higher when inoculated with strain VR218 as compared to other varieties inoculated with reference strain ZAE94 or fertilized with $100 \mathrm{~kg} \mathrm{~N} \mathrm{ha}^{-1}$. In a similar way, the variety Cana Forte produced significantly higher 1000-grain weight when inoculated with strains AR 2112 and AR1124 as compared with the N fertilization (Table 4). Analysis of the \% grain protein of these varieties showed that it was higher for varieties fertilized with $100 \mathrm{~kg} \mathrm{~N} \mathrm{ha}^{-1}$ as compared to the inoculated strains. Nevertheless, it could be seen that strains VR218, AR 2112 and BR2113 produced grains with higher \% protein and differed from the reference biofertilizer strain ZAE94 (Table 5). The traditional variety Come Cru produced grains with higher \% crude protein while this parameter was lowest for the commercial variety IR42.

Analysis of the field experiment showed that strain AR1122 promoted an increase of 10 and 29\%, respectively, in the grain yield of traditional variety Arroz 70 superior to the treatments fertilized with $100 \mathrm{~kg} \mathrm{Nha}^{-1}$ and the inoculated with reference strain ZAE 94 (Table 6). In the case of modern variety Bonança, inoculation of strains AR1122 and AR2112 also increased the grain yield but was only $3 \%$ superior to $\mathrm{N}$ fertilization and $1 \%$ in relation to the reference strain ZAE94 (Table 6). In contrast, the strain BR2113 reduced the grain yield mainly of the variety Arroz 70 and differed statistically from the strain AR1122. Overall, the modern variety Bonança produced higher grain yield and differed statistically from the traditional variety Arroz 70. In contrast to the pot experiment, no statistical difference in the yield component (weight of 1000 grains) was observed amongst the inoculated treatments. Nevertheless, 1000-grain weight was higher mainly for the treatments inoculated with the strains AR1122 and ZAE94 in the traditional variety Arroz 70 that presented heavier grains than the modern variety Bonança (Table 6 ). Similarly, the \% protein in the grain was slightly higher in the variety Arroz 70 although it did not differ from the variety Bonança (Table 6). However, a significant difference in the \% protein content of the grains was observed for the variety inoculated with the strains AR1122 and BR 2113 and reference strain ZAE 94 but it did not differ from the treatment with $100 \mathrm{~kg} \mathrm{Nha}^{-1}$.

\section{Discussion}

Although some traditional rice varieties (i.e. Arroz 70) responded positively to inoculation with few isolates, no significant interaction among isolates and rice genotypes were observed when evaluated under gnotobiotic growth conditions. Ferreira et al. (2003) also did not observe significant interactions among strains $H$. seropedicae ZAE94 and B. kururiensis M130 inoculated in the commercial varieties IR42 and IAC4440 grown in gnotobiotic conditions. In contrast, Didonet et al. (2003) observed a positive effect of Azospirillum strains on commercial rice varieties, recommended for dry-land soil regions, although the plants were only 7 days-old plants. It is already known that the plant response to IAA excreted 
Table 3

Grain yield $\left(\right.$ g pot $^{-1}$ ) response of six traditional rice varieties grown in pots and inoculated with strains selected from the gnotobiotic experiment.

\begin{tabular}{|c|c|c|c|c|c|c|c|}
\hline \multirow[t]{2}{*}{ Bacterial strains } & \multicolumn{7}{|c|}{ Rice varieties } \\
\hline & Arroz 70 & Braquiaria & Cana Forte & Come Cru & Bonança & IR42 & Means \\
\hline AR3122 & 7.15Bab & 7.6Bab & 6.91Bab & $6.21 \mathrm{Bb}$ & 6.52Bab & $9.23 \mathrm{Ab}$ & 7.27 \\
\hline VR218 & $6.59 \mathrm{ABbc}$ & 7.57Aab & 7.99Aa & $5.51 \mathrm{Bbc}$ & 6.76ABab & 7.56Acd & 7.00 \\
\hline AR2112 & 7.24Bab & $7.03 \mathrm{BCb}$ & $5.15 \mathrm{Dc}$ & $5.64 \mathrm{CDbc}$ & $5.55 \mathrm{Db}$ & 8.69Abc & 6.55 \\
\hline BF1358 & $6.25 \mathrm{ABbc}$ & 7.04ABb & $6.03 \mathrm{BCbc}$ & $4.77 \mathrm{Cc}$ & 6.41ABab & 7.66Acd & 6.36 \\
\hline BR2113 & 7.38Aab & $6.55 \mathrm{Ab}$ & $6.33 \mathrm{ABbc}$ & $5.06 \mathrm{Bbc}$ & $7.24 \mathrm{Aa}$ & 7.65Acd & 6.71 \\
\hline AR1124 & 7.3Aab & 7.11Ab & $6.11 \mathrm{ABbc}$ & $5.23 \mathrm{Bbc}$ & 7.15Aa & $7.24 \mathrm{Ad}$ & 6.69 \\
\hline AR1122 & 8.06Aa & $6.59 \mathrm{Bb}$ & $6.38 \mathrm{Bbc}$ & $5.83 \mathrm{Bbc}$ & 6.43Bab & $9.17 \mathrm{Ab}$ & 7.08 \\
\hline ZAE94 (ref. control) & $5.66 \mathrm{Cc}$ & $7.24 \mathrm{Bb}$ & 6.85BCab & $5.49 \mathrm{Cbc}$ & $5.96 \mathrm{BCab}$ & $8.72 \mathrm{Abc}$ & 6.56 \\
\hline $\mathrm{N}\left(100 \mathrm{~kg} \mathrm{Nha}^{-1}\right)$ & 6.96CDabc & 8.99Ba & 7.26CDab & $8.08 \mathrm{BCa}$ & 6.32Dab & $10.72 \mathrm{Aa}$ & 8.06 \\
\hline Means & 6.96 & 7.31 & 6.56 & 5.76 & 6.48 & 8.52 & \\
\hline C.V. (\%) & & & & 14.73 & & & \\
\hline
\end{tabular}

Means followed by the same letters (capital for varieties and lowercase for inoculation procedure) are not significantly different at a $5 \%$ probability by the $t$ test (LSD).

Table 4

Weight of 1000 grains ( $\mathrm{g} \mathrm{pot}^{-1}$ ) of six traditional rice varieties grown in pots and inoculated with strains selected from the gnotobiotic experiment.

\begin{tabular}{|c|c|c|c|c|c|c|c|}
\hline \multirow[t]{2}{*}{ Bacterial strains } & \multicolumn{7}{|c|}{ Rice varieties } \\
\hline & Arroz 70 & Braquiaria & Cana Forte & Come Cru & Bonança & IR42 & Means \\
\hline AR3122 & 26.63Bab & 30.56Aab & 27.52Bab & $22.27 \mathrm{Ca}$ & $28.25 \mathrm{ABa}$ & $23.13 \mathrm{Cbcd}$ & 26.39 \\
\hline VR218 & 27.95Ba & 31.20Aab & 26.24Bab & 22.93Ca & $26.98 \mathrm{Ba}$ & $26.56 \mathrm{Ba}$ & 26.98 \\
\hline AR2112 & $25.01 \mathrm{Cb}$ & 30.81Aabc & $27.65 \mathrm{Ba}$ & $22.90 \mathrm{Ca}$ & $27.49 \mathrm{Ba}$ & $23.87 \mathrm{Cbcd}$ & 26.29 \\
\hline BF1358 & 26.99BCab & $31.28 \mathrm{Aab}$ & 27.32Bab & $23.35 \mathrm{Da}$ & $27.24 \mathrm{Ba}$ & 24.63CDab & 26.80 \\
\hline BR2113 & 26.54Bab & 29.79Abc & 27.59ABab & $23.38 \mathrm{Ca}$ & $29.05 \mathrm{Aa}$ & $23.08 \mathrm{Cbcd}$ & 26.57 \\
\hline AR1124 & 26.39BCab & 30.93Aab & 28.14Ba & $23.51 \mathrm{Da}$ & $27.46 \mathrm{Ba}$ & 24.33CDabc & 26.79 \\
\hline AR1122 & 26.44Bab & 30.77Aabc & 27.06Bab & $22.78 \mathrm{Ca}$ & $26.85 \mathrm{Ba}$ & $21.76 \mathrm{Cd}$ & 25.95 \\
\hline ZAE94 (ref. control) & 26.76Bab & $32.51 \mathrm{Aa}$ & 26.70Bab & $23.62 \mathrm{Ca}$ & 28.99Ba & $21.87 \mathrm{Cd}$ & 26.74 \\
\hline $\mathrm{N}\left(100 \mathrm{~kg} \mathrm{Nha}^{-1}\right)$ & $24.62 \mathrm{Bb}$ & $28.45 \mathrm{Ac}$ & $25.26 \mathrm{Bb}$ & 24.6Ba & $21.63 \mathrm{Cb}$ & $21.96 \mathrm{Ccd}$ & 24.43 \\
\hline Means & 26.37 & 30.70 & 27.06 & 23.27 & 27.12 & 23.46 & \\
\hline C.V. (\%) & \multicolumn{7}{|c|}{6.46} \\
\hline
\end{tabular}

Means followed by the same letters (capital for varieties and lowercase for inoculation procedure) are not significantly different at a $5 \%$ probability by the $t$ test (LSD).

Table 5

Grain Protein content (\%) accumulated in the grain of six traditional rice varieties grown in pots and inoculated with strains selected from the gnotobiotic experiment.

\begin{tabular}{|c|c|c|c|c|c|c|c|}
\hline \multirow[t]{2}{*}{ Bacterial strains } & \multicolumn{7}{|c|}{ Rice varieties } \\
\hline & Arroz 70 & Braquiaria & Cana Forte & Come Cru & Bonança & IR42 & Means \\
\hline AR3122 & 5.62 & 7.72 & 5.69 & 7.24 & 7.12 & 5.53 & $6.32 \mathrm{bc}$ \\
\hline VR218 & 6.93 & 6.24 & 6.09 & 7.30 & 6.31 & 6.19 & $6.51 \mathrm{~b}$ \\
\hline AR2112 & 6.18 & 7.28 & 6.15 & 7.55 & 6.88 & 4.84 & $6.48 b$ \\
\hline BF1358 & 5.06 & 6.81 & 5.79 & 7.35 & 5.95 & 5.58 & $6.05 b c$ \\
\hline BR2113 & 5.35 & 6.57 & 7.07 & 7.82 & 6.35 & 5.16 & $6.43 b$ \\
\hline AR1124 & 4.68 & 6.38 & 6.13 & 8.18 & 6.29 & 5.42 & $6.18 \mathrm{bc}$ \\
\hline AR1122 & 5.51 & 6.80 & 5.17 & 6.04 & 6.33 & 5.64 & $5.92 \mathrm{bc}$ \\
\hline ZAE94 (ref. cont.) & 5.28 & 5.79 & 6.17 & 7.27 & 5.86 & 4.23 & $5.77 \mathrm{c}$ \\
\hline $\mathrm{N}\left(100 \mathrm{~kg} \mathrm{Nha}^{-1}\right)$ & 7.32 & 8.26 & 7.42 & 9.17 & 8.35 & 7.34 & $7.98 a$ \\
\hline Means & $5.77 \mathrm{DE}$ & $6.76 \mathrm{~B}$ & 6.19CD & $7.55 \mathrm{~A}$ & $6.61 \mathrm{BC}$ & $5.55 \mathrm{E}$ & \\
\hline C.V. (\%) & & & & 18.07 & & & \\
\hline
\end{tabular}

Means followed by the same letters are not significantly different at a 5\% probability by the $t$ test (LSD).

Table 6

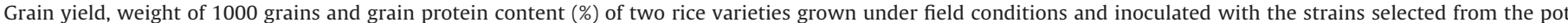
experiment.

\begin{tabular}{|c|c|c|c|c|c|c|c|c|c|}
\hline \multirow[t]{2}{*}{ Bacterial strains } & \multicolumn{3}{|c|}{ Yield $\left(\mathrm{kg} \mathrm{ha}^{-1}\right)$} & \multicolumn{3}{|c|}{ Weight 1000 grains $(\mathrm{g})$} & \multicolumn{3}{|c|}{ Grain protein content (\%) } \\
\hline & Arroz 70 & Bonança & Means & Arroz 70 & Bonança & Means & Arroz 70 & Bonança & Means \\
\hline AR1122 & 4336.2 & 5061.6 & 4698.9a & 28.7 & 25.0 & $26.8 \mathrm{a}$ & 8.75 & 8.25 & $8.50 a$ \\
\hline AR3122 & 3562.5 & 4884.7 & 4223.4ab & 25.9 & 25.1 & $25.5 a$ & 8.50 & 6.75 & $7.62 \mathrm{ab}$ \\
\hline AR2112 & 3006.4 & 5081.4 & 4043.9ab & 27.5 & 24.2 & $25.8 \mathrm{a}$ & 6.75 & 7.75 & $7.25 \mathrm{ab}$ \\
\hline BR2113 & 2550.5 & 4523.1 & $3536.8 b$ & 25.5 & 26.0 & $25.6 a$ & 6.50 & 6.50 & $6.50 \mathrm{~b}$ \\
\hline ZAE94 (ref. strain) & 3362.4 & 5011.9 & 4187.7ab & 29.6 & 25.3 & $27.8 \mathrm{a}$ & 7.00 & 6.50 & $6.75 b$ \\
\hline $\mathrm{N}\left(100 \mathrm{~kg} \mathrm{Nha}^{-1}\right)$ & 3931.5 & 4929.9 & $4430.7 \mathrm{ab}$ & 28.7 & 25.0 & $26.8 \mathrm{a}$ & 9.50 & 7.75 & $8.62 a$ \\
\hline means & 3458.3B & $4915.4 \mathrm{~A}$ & & $27.5 \mathrm{~A}$ & $25.2 \mathrm{~B}$ & & $7.83 \mathrm{~A}$ & $7.23 \mathrm{~A}$ & \\
\hline C.V. (\%) & 14.61 & & & 22.22 & & & 14.31 & & \\
\hline
\end{tabular}

Means followed by the same letters are not significantly different at a $5 \%$ probability by the $t$ test (LSD). 
by bacteria may vary from beneficial to inhibitory (Barazani and Friedman, 1999). Although no significant correlation was observed in the biomass accumulated (Table 2 ) and production IAA by the isolates (Table 1), there was a trend in the biomass produced and IAA detected in in vitro. The A. amazonense strains (AR3122 and VR218) and Sphingomonas strain AR2112 produced the highest amount of indols that may have influenced positively the biomass accumulated in the plants. Similarly, strains that produced lower amounts of indols, also promoted lower biomass accumulation in the traditional rice varieties. These results contrast with that reported by Rodrigues et al. (2008) that did not observe correlation between the production of indols by $A$. amazonense strains and plant growth development of commercial rice varieties IR42 and IAC4440. There is no clear explanation for these differences, although this effect was more pronounced for the traditional rice varieties than for modern varieties (Bonança and IR42). The new rice varieties have been developed for very efficient $\mathrm{N}$ fertilizer use and consequently high yield productivity (Taylaran et al., 2009), therefore an efficient interaction of beneficial diazotrophic strains and varieties may have been reduced during the breeding program.

In contrast to the results observed in the gnotobiotic conditions, the grain yield of rice varieties grown in pots varied in response to inoculation with the selected strains. The strain AR1122 vs. variety Arroz70, strain VR218 vs. variety Cana Forte and, strains BR213 and AR1124 vs. variety Bonança produced higher amount of grains than the treatment fertilized with $100 \mathrm{~kg} \mathrm{~N} \mathrm{ha}^{-1}$. In addition, many of these isolates also produced higher yield than the reference biofertilizer strain ZAE94. The strain ZAE 94 has been isolated from a commercial rice variety IR25 (Baldani et al., 2000) and inoculated in modern rice varieties such as IR42 and IAC 4440 with high yield response (Ferreira et al., 2010) but has not yet been evaluated in association with traditional rice varieties. The better response of traditional rice varieties to inoculation with strains isolated from soil collected in area cultivated with these varieties seemed to be a good strategy for selection of adapted strains able to establish a specific interaction and benefit these rice varieties. Interactions between diazotrophic strains and rice varieties have already been reported by Biswas et al. (2000) evaluating different strains in association with a traditional rice cutivar Pankaj and the modern variety IR72.

Many authors have already observed that the increment in grain yield of some inoculated rice genotypes correlates with an increase in the weight of 1000 grains (Tran Van et al., 2000; Govindarajan et al., 2008). In our study, it was observed that strain VR218 vs. variety Arroz70 and variety IR42, AR2112 and AR1124 vs. cultivar Cana Forte significantly increased the weight of 1000 grains with values even superior to the fertilization with $100 \mathrm{~kg} \mathrm{~N} \mathrm{ha}^{-1}$. As expected, the quality of the grains (\% crude protein) was higher when the varieties were fertilized with $100 \mathrm{~kg} \mathrm{~N} \mathrm{ha}^{-1}$ mainly for the varieties Come Cru and Brachiaria. Rodrigues et al. (2008) also observed lower $\mathrm{N}$ accumulation in the grain of the variety IR42 inoculated with different strains of $A$. amazonense when compared with $80 \mathrm{~kg} \mathrm{Nha}^{-1}$. Similarly, Ferreira et al. (2003) did not detect higher \% $\mathrm{N}$ in the grains of variety IR42 inoculated with strain ZAE 94. In our study, the commercial variety IR42 showed the lowest \% protein in the grain when inoculated with strain ZAE94 compared to the other strains. A large variability in the \% protein content (1.65-9.33\%) has already been observed among 48 rice varieties cultivated in India (Jugran et al., 2010) and this variability was much larger (4.4-20.2\%) in rice core collection grown in Brazil (Silveira et al., 2010). According the last authors there is no relationship between the \% grain protein, yield and origin of the varieties. Therefore, it seems that the effect observed here might be an indirect influence of the bacterial inoculation.
Evaluation of the field experiment involving the rice varieties and strains selected from their grain yield performance in the pot experiment, showed that the strain AR1122 (B. vietnamiensis) was the diazotrophic bacterium with the best performance to promote the grain yield increase of the traditional rice variety Arroz 70 cultivated in Maranhão State. More interesting, this isolate was capable to ensure a productivity superior to that obtained with $100 \mathrm{~kg} \mathrm{~N} \mathrm{ha}^{-1}$ and the reference strain ZAE94. The higher grain yield detected in the variety Bonança would be expected considering that it is a modern commercial variety and has been improved for higher productivity (Rotili et al., 2010). An interesting aspect was the higher \% of crude protein in the grain of both varieties inoculated with the strain AR1122 although no relationship was observed with the initial \% of crude grain protein for the varieties as established by Araújo et al. (2003). Other authors have also observed an increase in \% $\mathrm{N}$ in the grain of rice varieties inoculated with a commercial product BioGro grown in paddy rice region in Vietnam (Cong et al., 2009). The increments in the yield of the variety Arroz70 superior to the $\mathrm{N}$ fertilization may not be only attributed to the BNF process. Other factors such as phytohormones (GA3 and IAA) produced by diazotrophic strain (Chi et al., 2005) as well as the absorption of $\mathrm{N}$ by the roots (Saubidet et al., 2002) associated with other mechanisms such as P solubilization (Govindarajan et al., 2008) should also be considered.

These results suggest that a biofertilizer inoculation program for traditional rice varieties should consider the association between a specific strain and a variety cropped in the area. The reference biofertilizer strain ZAE94, isolated a long time ago from a commercial rice variety IAC25 (Baldani et al., 2000), has shown positive effect when inoculated in commercial rice varieties such as IR42 and IAC4440 (Guimarães et al., 2007; Ferreira et al., 2010) but not for the traditional cultivar Arroz 70 as well as for the other traditional varieties tested in pot conditions. Additional studies involving the inoculation of other traditional rice varieties with the B. vietnamiensis AR 1122 strain in Northeast rice region of Brazil, mainly Maranhão state, may help to confirm the straingenotype effect observed here. A question has been raised about the use of Burkholderia strains as biofertilizers in the agriculture mainly because this genus includes pathogenic species to human (Suárez-Moreno et al., 2012). However, it seems that this restriction does not apply to Burkholderia nitrogen-fixing species (Hirsch et al., 2012). These authors demonstrated, using various bioassays (for ex. Caenorhabditis elegans and HeLa cells), that this specific group is not pathogenic. In addition, it was also showed that these nitrogen-fixing species lack the T3SS secretion system and phylogenetical analyses, involving several housekeeping genes, suggested that these plant-beneficial species are clearly separated from the pathogenic ones. Therefore, the nitrogen-fixing $B$. vietnamiensis AR 1122 strain might be potentially beneficial and should be tested under different rice crop systems to confirm its biotechnological application as a commercial biofertilizer.

\section{Acknowledgments}

The authors thank CAPES and CNPq for the fellowships of the graduate student and research scientist and to Embrapa and FAPERJ for the financial support. Thanks also to the technician Aline Vieira for the 16S rRNA bacterial sequencing and Robert Boddey for the review and English correction of the manuscript.

\section{References}

Araújo, E.S., Souza, S.R., Fernandes, M.F., 2003. Características morfológicas e moleculares e acúmulo de proteína em grãos de variedades de arroz do Maranhão. Pesq. Agrop. Bras 38, 1281-1288.

Biswas, J.C., Ladha, J.K., Dazzo, F.B., 2000. Rhizobia inoculation improves nutrient uptake and growth of lowland rice. Soil Sci. Soc. Am. J. 64, 1644-1650. 
Baldani, J.I., Baldani, V.L.D., 2005. History on the biological nitrogen fixation research in graminaceous plants: special emphasis on the Brazilian experience. An. Acad. Bras. Cienc. 77, 549-579.

Baldani, V.L.D., Baldani, J.I., Dobereiner, J., 2000. Inoculation of rice plants with the endophytic diazotrophs Herbaspirillum seropedicae and Burkholderia spp. Biol. Fertil. Soils 30, 485-491.

Barazani, O., Friedman, J., 1999. Is IAA the major root growth factor secreted from plant-growth-mediating bacteria? J. Chem. Ecol. 25, 2397-2406.

Boddey, R.M., Oliveira, O.C., Urquiaga, S., Reis, V.M., Olivares, F.L., Baldani, V.L.D. Dobereiner, J., 1995. Biological nitrogen fixation associated with sugar cane and rice: contributions and prospects for improvement. Plant Soil 174, 195-209.

Buresh, R.J., Reddy, K.R., van Kessel, C., 2008. Nitrogen transformations in submerged soils. In: Schepers, J.S., Raun, W.R. (Eds.), Nitrogen in Agricultural Systems. Agronomy Monograph 49. ASA, CSSA, and SSSA, Madison, Wis., USA, pp. 401-436.

Chi, F., Shen, S.H., Cheng, H.P., Jing, Y.X., Yanni, Y.G., Dazzo, F.B., 2005. Ascending migration of endophytic rhizobia from roots to leaves inside rice plants and assessment of benefits to rice growth physiology. Appl. Environ. Microbiol. 71, 7271-7278.

Cong, P.T., Dung, T.D., Hien, T.M., Hien, N.T., Choudhury, A.T.M.A., Kecskés M.L., Kennedy, I.R., 2009. Inoculant plant growth-promoting microorganisms enhance utilisation of urea-N and grain yield of paddy rice in southern Vietnam. Eur. J. Soil Biol. 45, 52-61.

Didonet, A.D., Martin-Didonet, C.C.G., Gomes, G. F., 2003. Avaliação de linhagens de arroz de terras altas inoculadas com Azospirillum lipoferum Sp59 e A brasilense Sp245. Bol. Pesq. C. Nac. Pesq. Arroz e Feijão (online) 69, 1-4.

Elbeltagy, A., Nishioki, K., Sato, T., Suzuki, H., Ye, B., Hamada, T., Isawa, T., Mitsui, H. Minamisawa, K., 2001. Endophytic colonization and in plant nitrogen fixation by a Herbaspirillum sp Isolated from wild rice species. Appl. Environ. Microbiol. $67,5285-5293$

Engelhard, M., Hurek, T., Hurek, B.R., 2000. Preferential occurrence of diazotrophic endophytes Azoarcus spp. in wild rice species and land races of Oryza sativa in comparison with modern races. Environ. Microbiol. 2, 131-141.

FAO. Faostat Agriculture Data Available in: http://appsfaoorg/pag/collections? subset = agriculture. Accessed: 20 January 2006 .

Ferraz Junior, A.S.L., Souza, S.R., Fernandes, M.S., Rossiello, R.O.P., 1997. Eficiência do uso de nitrogênio para produção de grão e proteína por cultivares de arroz. Pesq. Agrop. Bras. 32, 435-442.

Ferreira, J.S., Sabino, D.C.C., Guimarães, S.L., Baldani, J.I., Baldani, V.L.D., 2003. Seleção de veiculo para o preparo de inoculante com bactérias diazotróficas para arroz inundado. Agron 37, 06-12.

Ferreira, J.S., Baldani, J.I., Baldani, V.L.D., 2010. Seleção de bactérias diazotróficas em duas variedades de arroz. Acta Sci. Agron. 32, 179-185.

Fonseca, J.R., Rangel, P.H., Bedendo, I.P., Silveira, P.M., Guimarães, E.P., Corandin, L. 1982. Características botânicas e agronômicas de cultivares e raças regionais de arroz (Oryza sativa L.) coletadas no Estado do Maranhão. Goiânia, EmbrapaCNPAF-Cernagen, $42 \mathrm{p}$

Govindarajan, M., Balandreau, J., Kwon, S-W., Weon, H-Y., Lakshminarasimhan, C. 2008. Effects of the inoculation of Burkholderia vietnamensis and related endophytic diazotrophic bacteria on grain yield of rice. Microb. Ecol. 55, 21-37.

Gregory, D.I., Haefele, S.M., Buresh, R.J., Singh, U., 2010. Fertilizer use, markets, and management. In: Pandey, S., Byerlee, D., Dawe, D., Achim Dobermann, A Mohanty, S., Rozelle, S., Bill Hardy, B. (Eds.), Rice in the Global Economy: Strategic Research and Policy Issues for Food Security. International Rice Research Institute, Los Baños, Philippines, pp. 231-263, Chapter 2.3, 477 pp.

Guimarães, S.L., Baldani, J.I., Baldani, V.L.D., 2003. Efeito da inoculação de bactérias diazotróficas endofíticas em arroz de sequeiro. Agron 37, 25-30.

Guimarães, S.L., Baldani, J.I., Baldani, V.L.D., Jacob-Neto, J., 2007. Adição de molibdênio ao inoculante turfoso com bactérias diazotróficas usado em duas cultivares de arroz irrigado. Pesq. Agropec. Bras. 42, 393-398.

Hardoim, P.R., Andreote, F.D., Reinhold-Hurek, B., Sessitsch, A., van Overbeek, L.S. van Elsas, J.D., 2011. Rice root-associated bacteria: insights into community structures across 10 cultivars. FEMS Microbiol. Ecol. 77, 154-164.

Hirsch, A., Angus, A.A., Weinstock, G., Estrada-de los Santos, P., Walker, R.M., 2012. 13th Symposium on Biological Nitrogen Fixation with Non-Legumes,
Neuherberg, Munich, Germany, 6-7 September 2012. Plant-associated Burkholderia species fix nitrogen, solubilize phosphate, promote plant growth, and are phylogenetically distinct from disease-causing species, 17.

Jugran, A., Bhatt, I.D., Rawal, R.S., 2010. Characterization of agro-diversity by seed storage protein electrophoresis: focus on rice germplasm from Uttarakhand Himalaya. India. Rice Sci. 17, 122-128.

Knauth, S., Hurek, T., Brar, D., Reinhold-Hurek, B., 2005. Influence of different Oryza cultivars on expression of nifH gene pools in roots of rice. Environ. Microbiol. 7 , $1725-1733$

Juliano, B.O., 1985. Polysaccharides proteins and lipids of rice. In: Juliano, B.O. (Ed.), Rice: chemistry and technology. , 2nd ed. American Association of Cereal Chemists, St. Paul, pp. 59-175.

Ladha, J.K., Reddy, P.M., 2003. Nitrogen fixation in rice systems: state of knowledge and future prospects. Plant Soil 252,151-167.

Malarvizhi, P., Ladha, J.K., 1999. Influence of available N and rice genotype on associative nitrogen fixation. Soil Sci. Soc. Am. J. 63, 93-99.

Mohanty, S., Wailes, E., Eddie Chavez, E., 2010. The global rice supply and demand outlook: the need for greater productivity growth to keep rice affordable. In: Pandey, S., Byerlee, D., Dawe, D., Achim Dobermann, A., Mohanty, S., Rozelle S., Bill Hardy, B. (Eds.), Rice in the Global Economy: Strategic Research and Policy Issues for Food Security. International Rice Research Institute, Los Baños, Philippines, pp. 175-187, Chapter 1.7, 477 pp.

Peng, S., Biswas, J.C., Ladha, J.K., 2002. Influence of rhizobial inoculation on photosynthesis and grain yield of rice. Agron. J. 94, 925-929.

Rodrigues, E.P., Rodrigues, L.S., Oliveira, A.L.M., Baldani, V.L.D., Teixeira, K.R.S. Urquiaga, S., Reis, V.M., 2008. Azospirillum amazonense inoculation: effects on growth yield and $\mathrm{N}_{2}$ fixation of rice (Oryza sativa L.). Plant Soil 302, 249-261.

Rotili, E.A., Fidelis, R.R., Santos, M.M., Barros, H.B., Pinto, L.C., 2010. Eficiência do uso e resposta à aplicação de fósforo de cultivares de arroz em solos de terras altas. Bragantia 69, 705-710.

Saravanan, V., Madhaiyan, M., Osborn e, J., Thangaraju, M., As, T., 2008. Ecologica occurrence of Gluconacetobacter diazotrophicus and nitrogen-fixing Acetobacteraceae members their possible role in plant growth promotion. Microb. Ecol. 55 $130-140$.

Sasaki, K., Ikeda, S., Eda, S., Mitsui, H., Hanzawa, E., Kisara, C., Kazama, Y., Kushida, A., Shinano, T., Minamisawa, K., Sato, T., 2010. Impact of plant genotype and nitrogen level on rice growth response to inoculation with Azospirillum sp. strain B510 under paddy field conditions. Soil Sci. Plant Nutr. 56, 636-644.

Saubidet, M.I., Fatta, N., Barneix, A.J., 2002. The effect of inoculation with Azospirillum brasilense on growth and nitrogen utilization by wheat plants. Plant Soil 245 , 215-222.

Silveira, R.D.D., Santos, K.F.N., Didonet, C.C.G.M., Didonet, A.D., Brondani, C., 2010 Proteínas de reserva de acessos de coleção nuclear de arroz. Pesq. Agrop. Bras. $45,1441-1447$

Suárez-Moreno, Z.R., Caballero-Mellado, J., Coutinho, B.G., Mendonça-Previato, L. James, E.K., Venturi, V., 2012. Common features of environmental and potentially beneficial plant-associated Burkholderia. Microb. Ecol. 63, 249-266.

Taylaran, R.D., Ozawa, S., Miyamoto, N., Ookawa, T., Motobayashi, T., Hirasawa, T. 2009. Performance of a high-yielding modern rice cultivar Takanari and several old and new cultivars grown with and without chemical fertilizer in a submerged paddy field. Plant Prod. Sci. 12, 365-380.

Tedesco, M.J., Gianello, C., Bissani, C.A., Bohnen, H., Volkweiss, S.J., 1995. Análise de solos plantas e outros materiais. 2nd edition. Porto Alegre: UFRGS, Brazil, p. 174

Timmer, C.P., Block, S., Dawe, D., 2010. Long-run dynamics of rice consumption, 1960-2050. In: Pandey, S., Byerlee, D., Dawe, D., Achim Dobermann, A., Mohanty, S., Rozelle, S., Bill Hardy, B. (Eds.), Rice in the Global Economy: Strategic Research and Policy Issues for Food Security. International Rice Research Institute, Los Baños, Philippines, pp. 139-173, Chapter 1.6, 477 pp.

Tran Van, V., Berge, O., Ngô Kê, S., Balandreau, J., Heulin, T., 2000. Repeated beneficia effects of rice inoculation with a strain of Burkholderia vietnamiensis on early and late yield components in low fertility sulphate acid soils of Vietnan. Plant Soil $218,273-284$

Videira, S.S., Araújo, J.L.S., Rodrigues, L.S., Baldani, V.L.D., Baldani, J.I., 2009. Occurrence and diversity of nitrogen-fixing Sphingomonas bacteria associated with rice plants grown in Brazil. FEMS Microbiol. Lett. 293, 11-19. 